\title{
ROLE IN MONITORING COMMITTEE IMPROVING COMPLIANCE WITH TAX PAYERS AND EFFECT ON REVENUE TAX INCREASE PERSPECTIVE ON ADMINISTRATION
}

\author{
Hadi Masyhur \\ Dosen Tetap STIE Tridharma dan Dosen Luar Biasa pada FEB \\ Universitas Kristen Maranatha dilingkungan Kopertis Wilayah IV Jawa Barat dan Banten
}

\begin{abstract}
Applicable taxes in Indonesia can be differentiated taxation based on the parties to bear, the party picked up, and nature. Good service will encourage taxpayer compliance to implement taxation obligations. To be able to improve taxpayer compliance is by listening, seeking out and trying to meet what is desired by the taxpayer regarding the rights and obligations of taxation. The desire or the means to listen to the voice of taxpayers in many countries known as the Tax Ombudsman in Indonesia called the Supervisory Committee of Taxation (KPPer). Giving you the best possible service to taxpavers will increase the level of taxpaver compliance. The high level of taxpaver compliance by itself will increase tax revenues. KPPer is to ensure that the taxpayer has be best served by the DGT, namely: (1) ensure that the taxpayer has been given the ministry (in terms of policy, legal, and administrative), (2) Directorate General of Taxation to give optimal service, (3) KPer and DGT synergistically provide optimum services and in turn increase tax revenue will be achieved. In other words, the formation of synergies between the DGT and KPPer can increase tax revenues.
\end{abstract}

Keywords: watchdog Committee of taxation, taxpayer compliance, tax administration, the parties bear, the party picked up, the nature of the tax

\begin{abstract}
ABSTRAK
Pajak yang berlaku di Indonesia dapat dibedakan pajak berdasarkan atas pihak yang menanggung, pihak yang memungut, dan sifatnya.Pelayanan yang baik akanmendorong kepatuhan wajib pajak untuk melaksanakan kewajiban perpajakannya. Untuk dapat meningkatkan kepatuhan wajib pajak yaitu dengan caramendengar, mencari tahu dan berupaya untuk memenuhi apa yang dinginkan oleh wajib pajak terkait dengan hak dan kewajiban perpajakannya. Sarana untuk mendengarkan keinginan atau suara wajib pajak dibanyak negara dikenal dengan namaTax Ombudsmandi Indonesia namanya Komite Pengawas Perpajakan (KPPer). Pemberian pelayanan yang sebaik mungkin kepada wajib pajak akan menaikkan tingkat kepatuhan wajib pajak. Tingginya tingkat kepatuhan wajib pajak dengan sendirinya akan meningkatkan penerimaan pajak. KPPer adalah untuk memastikan bahwa wajib pajak telah dilayani sebaik mungkin oleh DJP, yaitu:(1) memastikan wajib pajak telah diberi pelayanan (dalam hal kebijakan, hukum, dan administrasi); (2) Dirjen Pajak memberikan pelayanan optimal; (3)KPer dan DJP secara sinergi memberikan pelayanan yang optimal dan pada gilirannya peningkatan penerimaan pajak akan tercapai. Dengan kata lain terbentuknya sinergi antara DJP dan KPPer dapat meningkatkan penerimaan pajak.
\end{abstract}

Kata kunci: Komite pengawas perpajakan, kepatuhan wajib pajak, administrasi pajak, pihak yang menanggung, pihak yang memungut, sifat pajak 


\section{PENDAHULUAN}

Dalam menjalankan fungsinya, pemerintah atau penguasa suatu negara membutuhkan sumber pendanaan atau modal.Salah satu sumber pendanaan tersebut diperoleh dari pemungutan pajak yang berasal dari Warga Negara yang bersangkutan.Selain dengan itu, berdasarkan literatur-literatur pajak umum, diketahui bahwa fungsi pajak adalah fungsi budgetair atau anggaran disamping fungsi regulerend (mengatur). Pajak merupakan suatu gejala sosial yang timbul dalam suatu masyarakat. Menurut masyarakat disini maksudnya adalah masyarakat hukum atau gemeinschaft. Adanya proses timbal balik antara individudan masyarakat berdampak kepada hubungan timbal balik hak dan kewajiban yang melekat pada masyarakat (Ferdinand, 2001).Dengan kata lain terdapat hak dan kewajiban individu terhadap masyarakat, dan sebaliknya, terdapat juga hak dan kewajiban masyarakat terhadap individu.

Pajak sebagai salah satu instrumen kebijakan fiskal dan merupakan instrumen utama dalam pemasukan Negara. Dalam system ekonomi, keberadaan pajak digunakan untuk pembangunan serta kesejahteraan rakyat. Jika Negara punya system pajak untuk meredistribusikan sumber daya ekonomi yang dikuasai oleh warganya, maka kepatuhan warganya sangat diperlukan. Namun permasalahan yang mucul saat ini jika dalam setiap warga negara sudah ada kewajiban untuk mengeluarkan sebagian hartanya (dalam hal ini pajak) berdasarkan ketentuan yang berlaku, maka bagi Warga Negara yang patuh dapatkah menuntut pelayanan yang optimaldari penyelenggara negara atau reward dalam bentuk apa saja (system hukum, system ekonomi, system politik dan lainnya) yang membuat warga negaranya nyaman.

Jika dalam suatu negara tingkat kepatuhan wajib pajak dalam membayar pajak sangat tinggi dengan sendirinya tentu akan meningkatkan penerimaan pajak. Dengan demikian, pertanyaan kuncinya adalah bagaimana meningkatkan kepatuhan wajib pajak?. Tentunya dengan cara memaksimalkan alokasi anggaran yang berasal dari pajak tersebut untuk sebesar-besarnya bagi kemakmuran wajib pajak. Selain itu, sebagai bentuk penghargaan kepada wajib pajak yang telah membiayai pembangunan negara, sudah sepantasnya wajib pajak harus diberikan pelayanan sebaik mungkin dalam memenuhi kewajiban perpajakannya.

Pelayanan yang baik akan mendorong kepatuhan wajib pajak untuk melaksanakan kewajiban perpajakannya. Untuk dapat meningkatkan kepatuhan wajib pajak yaitu dengan cara mendengar, mencari tahu dan berupaya untuk memenuhi apa yang diinginkan oleh wajib pajak terkait dengan hak dan kewajiban perpajakannya. Sarana untuk mendengarkan keinginan atau suara wajib pajak dibanyak negara dikenal dengan namaTax Ombudsman atau di Amerika Serikat dikenal dengan nama National Taxpayer Advocate (Bentley, 1998:28) dengan slogannya "Your Voice at the IRS".

Peningkatan kepatuhan wajib pajak merupakan tujuan utama yang hendak dicapai oleh berbagai otoritas pajak di dunia. Untuk mencapai tujuan tersebut, pemberian pelayanan yang sebaik mungkin, diyakini dapat mendorong kepatuhan wajib pajak dalam membayar pajak yang hal ini sesuai pengarahan DJP1 Jabar (Ka Kanwil Pajak Jabar) Drs. Dedi Rudaedi,MSc.,Ak., pada seminar perpajakan awal juni 2011 yang bertempat di Gedung GAP Lt. 8, Universitas Kristen Maranatha, berjudul :"Strategi Pengamanan Penerimaan Pajak tahun 2011 saat DJP diterpa Badai". Organisasi kerjasama ekonomi negara-negara maju (OECD) menyatakan bahwa pelayanan kepada wajib pajak dengan memberikan perlakuan pajak yang fair dan efisien akan mendorong tingkat kepatuhan wajib pajak (OECD, 2001). Hal ini pula diyakini oleh otoritas pajak Belanda (The Dutch Tax and Customs Administration) yang menyatakan dalam visinya bahwa tingkat kepatuhan wajib pajak akan dicapai melalui peningkatan pelayanan kepada wajib pajak (Alink dan Kommer, 2009:17). Untuk itulah, di Bangladesh, didirikan tax ombudsman yang bertujuan untuk meningkatkan hubungan antara wajib pajak dan otoritas pajak melalui peningkatkan pelayanan kepada wajib pajak yang akan berdampak terhadap peningkatan penerimaan pajak(Scales, 2005: 222).

Dalam implementasinya, indikator (tolak ukur) pelayanan kepada wajib pajak didasarkan atas hak-hak dasar wajib pajak yang biasanya di negaranegara maju (developing country) dinyatakan dalam taxpayers' rights yang elemennya terdiri sebagai berikut (Hamilton, 2003: 571-572):(1) Hak untuk mendapatkan informasi, bantuan dan didengar keluhannya; (2) Hak untuk mengajukan banding; (3) Hak untuk hanya membayar pajak yang seharusnya terutang menurut ketentuan peraturan perundangundangan dan tidak lebih dari yang seharusnya; (4) Hak untuk mendapatkan kepastian hukum; (5) Hak atas jaminan tidak dilanggarnya hak-hak pribadi (privacy) wajib pajak serta; (6) Hak atas kerahasiaan. 
Dengan diberikannya hak-hak dasar tersebut dalam suatu sistem perpajakan, maka tuntutan atas pelaksanaan kewajiban perpajakan yang harus dilaksanakan oleh wajib seperti: (1) Kewajiban untuk berlaku jujur; (2) Kewajiban untuk dapat bekerjasama secara positif; (3) Kewajiban untuk menyediakan data secara akurat dengan tepat waktu; (4) Kewajiban untuk melakukan penyimpanan data; dan (5) Kewajiban untuk membayar pajak dengan tepat waktu; akan lebih mudah untuk dilakukan.

\section{PEMBERLAKUAN PERPAJAKAN DI INDONESIA}

Secara umum, pajak yang berlaku di Indonesia dapat dibedakan pajak berdasarkan atas :pihak yang menanggung, berdasarkan pihak yang memungut, dan berdasarkan sifatnya.

\section{Pihak yang Menanggung}

Berdasarkan pihak yang menanggung, dibagi menjadi: (1) Pajak Langsung, adalah yang pembayarannya harus ditanggung sendiri oleh Wajib Pajak dan tidak dapat dialihkan kepada pihak lain, Contoh: PPh, BPHTB; (2) Pajak Tidak Langsung, adalah pajak yang pembayarannya dapat dialihkan kepada pihak lain. Contoh: Pajak Penjualan Barang Mewah (PPn BM), PPN, Bea Materai dan Cukai.

\section{Pihak yang Memungut}

Berdasarkan pihak yang memungut, maka pajak pajak dibagi menjadi: (1) Pajak Negara atau Pajak Pusat, adalah pajak yang dipungut oleh pemerintah pusat. Pajak pusat merupakan salah satu sumber penerimaan negara yang utama. Contoh: Pajak Penghasilan (PPh), Pajak Bumi dan Bangunan (PBB), Pajak Pertambahan Nilai atas Barang dan Jasa (PPN), Pajak Penjualan atas Barang Mewah (PPn BM), Bea Meterai, Bea Perolehan Hak Atas Tanah dan Bangunan (BPHTB); (2) Pajak Daerah, adalah pajak yang dipungut oleh pemerintah daerah. Pajak daerah merupakan salah satu sumber penerimaan pemerintah daerah (pemerintah kota/kabupaten). Contohnya pajak tontonan, pajak reklame,PKB (Pajak Kendaraan Bermotor) PBB serta retribusi, contohnya: Retribusi iuran kebersihan, Retribusi terminal, Retribusi parkir, Retribusi galian pasir dan sebagainya.

\section{Berdasarkan Sifatnya}

Berdasarkan sifatnya, pajak dibagi menjadi: (1) Pajak Subjektif, adalah pajak yang memperhatikan kondisi keadaan Wajib Pajak. Dalam hal ini penentuan besarnya pajak harus ada alasan objektif yang berhubungan erat dengan kemampuan membayar wajib pajak. Contoh: PPh; dan (2) Pajak Objektif, adalah pajak yang berdasarkan pada objeknya tanpa memperhatikan keadaan diri Wajib Pajak. Contoh: PPN, PBB, PPn-BM.

\section{PRINSIP-PRINSIP ADMINISTRASI PERPAJAKAN \\ Hak-hak adminisratif Wajib Pajak adalah hak-} hak yang tidak harus diatur atau ditemukan secara eksplisit dalam Undang-undang. Hak administratif ini umumnya diberikan dalam konteks prosedur-prosedur yang rinci sehingga sangat tidak efisien jikka seluruhnya diatur dalam undang-undang, dan seringkali berbentuk pedoman-pedoman yang dikeluarkan oleh otoritas pajak. Namun pemerintah suatu negara umumnya cenderung memasukkan hak-hak administratif menjadi hak-hak hukum karena beberapa alasan (Widodo dan Djefris, 2008).

Hak-hak administratif tersebut bersifat fleksibel. Suatu kelonggaran atau kemudahan bisa saja diberikan, namun tidak dengan mudah untuk diperoleh oleh siapapun. Sebagai contoh, di Australia, terdapat hak-hak hukum yang memberikan privilege bagi professional untuk merahasiakan komunikasikomunikasi atau dokumen-dokumen dalam kaitannya dengan proses di pengadilan, atau bagi konsultasi hukum dari pengacara kepada kliennya. Kepala Otoritas Pajak memilih langkah untuk memperluas hak tersebut hingga juga mencakup dokumen-dokumen tertentu lainnya dan pihak-pihak yang lebih luas termasuk akuntan. Walaupun belakangan Kepala Otoritas Pajak tersebut menyadari bahwa kelonggaran ini telah disalahgunakan, dan memberikan indikasi bagi Australian Tax Office (ATO) untuk segera menarik peraturan tersebut.

llustrasi tersebut di atas juga memperlihatkan kemampuan hak administrative untuk diperluas tanpa dibatasi oleh hukum atau Undang-undang. Menyangkut adanya kemampuan untuk menarik suatu kelonggaran atau konsesi karena memang dibutuhkan, administratur pajak sering kali berkeinginan untuk memperluas hak-hak yang mereka dapat tawarkan kepada Wajib Pajak dalam rangka meningkatkan hubungan baik diantara mereka di masa-masa mendatang. Seperti umumnya yurisdiksi-yurisdiksi pajak lainnya, di Indonesia ketentuan tentang hak-hak administratif sebagian diatur dalam Undang-undang. Undang-undang No 6 tahun 1983 sebagaimana STDD Undang-undang No 16 tahun 2000 STDD 
Undang-undang No 28 tahun 2007 danterakhir telah dirubah dengan Undang-undang No 16 tahun 2009, yang mengatur tentang Ketentuan Umum dan Tata Cara Perpajakan. Undang-undang ini merupakan hukum formal yang berisi ketentuan-ketentuan dan tata cara pelaksanaan hukum pajak materilnya (Undang undang PPh dan Undang undang PPN dan PPnBM). Namun demikian, pengaturan administrasi yang lebih rinci telah didelegasikan kepada peraturanperaturan yang lebih rendah seperti Peraturan Pemerintah (PP) No 80 tahun 2007 tentang : tata cara Pelaksanaan Hak dan Kewajiban Perpajakan, Peraturan Menteri Keuangan (PMK), PP No 181/PMK 03/2007 tentang : bentuk dan isi, tata cara pengambilan, penanda-tanganan serta penyampaian SPT. Peraturan Menteri Keuangan (PMK), Keputusan DJP (Kep) dan Surat Edaran (SE). Hak-hak administratif Waijb Pajak secara selektif akan termasuk dalam setiap ketentuan-ketentuan administrasinya.

Dengan demikian di Indonesia belum terdapat semacam Bill of Taxpayers' Rights atau Taxpayers' Charter seperti di beberapa negara lain, yang betul-betul mendeklarasikan hak-hak Wajib Pajak yang patut untuk diperhatikan danjuga dilindungi. Hak-hak administratif dapat membantu administratif pajak meningkatkan goodwill Wajib Pajak yang akan diperoleh sebagai akibat meningkatnya kepatuhan Wajib Pajak dalam menjalankan kewajiban administrasi pajaknya. Beberapa hak-hak administratif Wajib Pajak akan dijelaskan selanjutnya dalam kemasan fungsi-fungsi pelaksanaan administrasi perpajakan sebagaimana terlampir dibawah ini.

\section{Prinsip Waktu yang Tepat dan Pemberitahuan yang Layak}

Ketika Wajib Pajak dihadapkan pada suatu keputusan atau penindakan oleh fiscus (petugas pajak), maka hal-hal tersebut seharusnya terkait dengan tindakan hukum atau aktifitas yang terjadi dalam suatu rentang waktu yang tertentu atau dalam waktu yang tepat menurut peraturan. Sudah selayaknya ketika Wajib Pajak diminta untuk melakukan sesuatu, memberikan informasi, atau halhal lainnya yang sebenarnya akan membantu tugas administrasi Kantor Pajak (Self Assessment System), maka hal tersebut dapat terjadi setelah Wajib Pajak diberi pemberitahuan yang layak. Kecuali sudah jelas apabila informasi yang menjadi perhatian tersebut secara logika sangat berpengaruh terhadap keberhasilan tindakan administratif yang diambil berkaitan dengan Wajib Pajak.
Statistik laporan lembaga ombudsman di sebagian besar yurisdiksi (wilayah hukum pajak) menunjukkan bahwa penundaan, kesalahan, dan kesalahfahaman dalam pelaporan pajak merupakan masalah yang cukup banyak ditangani kantor-kantor pajak. Pembuat peraturan dan perUndang-undangan pajak, dalam memenuhi tuntutan kepastian hukum, menentukan batas-batas waktu di mana Wajib Pajak dapat memenuhi kewajiban-kewajiban mereka. Hal tersebut sedikit membantu untuk memberikan pembatasan waktu bagi kantor pajak untuk bertindak di luar prosedur-prosedur formal. Otoritas pajak (semestinya) memahami kewajiban mereka untuk bertindak secara adil, efektif dan efisien.Bukanlah sesuatu yang bijak dalam suatu sistem pendataan yang baik, apabila mereka melakukan penundaanpenundaan sehingga keluhan-keluhan berkaitan dengan sistem pajak semakin menumpuk.OECD GAP 002 pada Model Administrative Charternya memuat sejumlah hak-hak tentang penanganan dalam suatu rentang waktu tertentu yang harus diperhatikan, sementara yang lainnya yang harus ditanggapi dengan 'prinsip sesegera mungkin'.

Prinsip-prinsip waktu yang tepat dan pemberitahuan yang layak menjadi penopang Centra Interamericano de Administraticiones Tributarias (CIAT), "minimum necessary attributes for a sound and effective tax administration" atau "kelengkapan penting minimum bagi suatu adiministrasi pajak yang sehat dan efektif' ". Karena itu prinsip-prinsipini sangat penting keberadaanya untuk menjamin terselenggaranya pencatatan pajak yang baik. Bagaimanapun, adalah penting untukmenjadikan prinsip-prinsip tersebut sebagai peraturan yang berlaku umum, daripada sekedar menjadikannya suatu syarat khusus dalam keadaan tertentu. Sebagai aturan yang berlaku umum, prinsip-prinsip tersebut dapatmenjadi pelindung dari sejumlah tindakan-tindakan yang tidak pantas dalam suatu periode waktu tertentu.Idealnya, prinsip-prinsip tersebut dapat memuat pengaturan yang menyediakan pilihan judicial review bagipihakpihak yang merasa tidak puas.

Penerapan prinsip-prinsip waktu yang tepat dan pemberitahuan yanglayak di Indonesia mungkin dapat kita lihat dari keberadaan aturan tersebutdalam Undang-undang No 16 tahun 2009 tentang Ketentuan Umum danTata cara Perpajakan (KUP). Undang-undang KUP banyak mengatur tentang hak dan kewajiban Wajib Pajak sehubungan dengan kelayakan informasi dan pelaporan sertaketepatan waktu untuk menyampaikan informasi dan laporan 
tersebut. Pasal 4 menyatakan bahwa Wajb Pajak, wajib mengisi dan menyampaikan Surat Pemberitahuan (SPT) dengan benar, lengkap, jelas, dan menandatanganinya (ayat 1). Kemudian pada ayat 4, ada kewajiban bagi Wajib Pajak yang diwajibkan menyelenggarakan pembukuan untuk melampiri SPT dengan laporan keuangan berupa neraca dan laporan labarugi serta keterangan lain yang diperlukan untuk menghitung besarnya Penghasilan Kena Pajak. Laporan Keuangan tersebut adalah laporan keuangan dari masing-masing Wajib Pajak (4a) dan jika telah diaudit makaharus melampirkan laporan keuangan yang telah diaudit oleh Akuntan Publik (4a). Jika tidak dapat dianggap SPT tidak lengkap dan tidak jelas, dan dianggap tidak disampaikan sebagaimana yang dimaksud dalam Pasal 3 ayat (7) huruf b.

Kemudian pelaporan tersebut juga harus tepat waktu, atau dalam kurun waktu yang ditentukan oleh undang-undang. Ini ditegaskan dan diatur dalam Pasal 6. Kemudian pada pasal 7, akan ada sanksi jika tidak menyampaikan laporan pada waktu yang telah ditentukan. Namun ada hak Wajib Pajak untuk mengajukan permohonan perpanjangan waktu penyampaian SPT yang diatur dalam Pasal 3 ayat (4). Adalah hak disamping kewajiban bagi Wajib Pajak untuk memberikan informasi yang selengkaplengkapnya tentang obyek pajak yang dimiliki. Jika suatu ketika terdapat informasi yang ingin ditambahkan, apakah karena kesadaran sendiri atau karena baru terungkap belakangan, makaberdasarkan Pasal 8 ayat (1), Wajib Pajak dengan kemauan sendiri dapat membetulkan SPT yang telah disampaikan dengan menyampaikan pernyataan tertulis, dengan syarat Direktur Jenderal Pajak belum melakukan tindakan pemeriksaan. Jika karena pembetulan tersebut akan berakibat rugi atau lebih bayar, pembetulan SPT harus disampaikan paling lama 2 (dua) tahun sebelum daluwarsa penetapan (ayat la).

Meski DJP telah melakukan tindakan pemeriksaan, sepanjang belum dilakukan tindakan penyidikan mengenai adanya ketidakbenaran (menurut ketentuan dalam Pasal 38) yang dilakukan Wajib Pajak, maka terhadap ketidakbenaran perbuatannya tersebut tidak akan dilakukan penyidikan, apabila dengan kemauan sendiri mengungkapkannya dengan disertai pelunasan kekurangan pembayaran jumlah pajak yang sebenarnya terutang beserta sanksi administrasi (ayat 3). Jika DJP telah melakukan pemeriksaan, namun belum menerbitkan Surat Ketetapan Pajak (ayat 4), ataupun telah menerbitkan
Surat Ketetapan Pajak (ayat 5), Wajib Pajak masih dapat mengungkapkan dengan kesadaran sendiri dalam laporan tersendiri tentang ketidakbenaran pengisian SPT yang telah disampaikan sesuai keadaan yang sebenarnya, dengan memenuhi syaratsyarat yang diatur pada ayat-ayat tersebut.

\section{Prinsip Keadilan dalam Tindakan Administratif}

Terdapat aturan tegas yang diterima secara umum tentang keadilan dalam tindakan administratif. Kita telah mengetahui bahwa dalam system hukum Common Law. Prinsip-prinsip tersebut diwujudkan dalam istilah PTA (Pemeriksaan Tindakan Adminstratif). Dalam sistem hukum Civil Law,prosedur administratif biasanya diatur dengan jelas dalam suatu peraturan perundang-undangan.Salah satu contoh yang dapat berguna tentang pentingnya prinsip keadilan dalam setiap tindakan administratif, adalah apa yang diterapkan dalam Section 3 of the Sout African Promotion of Justice Act 2000. "Syarat-syarat bagi tindakan administratif yang adil dan diinginkan secara prosedural", yaitu: (1) Perhatian yang diberikan cukup memadai bagi keadaan dan tujuan tindakan administratif yang dilakukan; (2) Kesempatan yang diberikan cukup untuk membuat keputusan; (3) Adanya penjelasan bagi tindakan administratif yang dijatuhkan; (4) Perhatian yang memadai/Pemberian kesempatan bagi pengajuan setiaphak pemeriksaan dan tuntutan internal, di mana hal tersebut memungkinkan untuk dilaksanakan; dan (5) Perhatian yang memadai bagi hak untuk meminta alasan-alasan.

Ini merupakan syarat-syarat yang jelas, sederhana, dan langsung pada sasaran yang diterima secara umum.

\section{Prinsip Publikasi, Penyebaran Informasi, dan Edukasi}

Semua peraturan yang diterapkan dalam Sistem Perpajakan harus dikompilasi (dikumpulkan dalam satu buku) dan dipublikasikan dengan tepat dan dalam satu bentuk yang dapat diakses oleh semua orang yang membutuhkannya. Hal tersebut penting untuk efektifitas system perpajakan. Kecuali Wajib Pajak mengetahui bahwa mereka diharapkan untuk membayar pajak dalam situasi tertentu dan mengetahui bagaimana melaksanakannya, maka sulit bagi mereka untuk mengajukan keluhan.

Seiring dengan berkembangnya penelitian dalam bidang pajak, maka bertambah pula bukti-bukti yang menunjukkan bahwa pembayaran pajak 
meningkat seiring dengan meningkatnya publikasi dan penyebaran informasi, beserta makin terdidiknya Wajib Pajak tentang hak-hak dan kewajiban perpajakannya. Sistem perpajakan sangat dinamis dan senantiasa berubah sehingga penyebaran informasi dan pendidikan merupakan sebuah kepentingan apabila para Wajib Pajak turut mengamati adil tidaknya sistem perpajakan.Semakin banyak informasi yang tersedia, maka semakin tinggi pula pemahaman para Wajib Pajak akan tugas mereka untuk memenuhi kewajiban yang telah dibebankan sistem perpajakan atas mereka.Kebanyakan otoritas pajak memiliki atau mendorong munculnya lembaga pendidikan dan program-program pendidikan masyarakat bagi perpajakan.

Salah satu contoh di Jepang, pemerintah sangat berkomitmen mengembangkan dan menumbuhkan komunitas serta sekolah-sekolah yang memberikan pendidikan di bidang perpajakan. Internet telah mengubah kemampuan otoritas pajak untuk menyediakan sejumlah besar informasi yang relatif murah dan mudah diakses bagi siapa saja. Publikasi, penyebaran informasi, pendidikan, dan bantuan (penjelasan) merupakan perlengkapan penting bagi pemeriksaan dan administrasi pajak yang efektif. Keempat hal tersebut harus dijadikan sebagai prinsipprinsip yang menjadi dasar administrasi pajak.

Bagaimana prinsip-prinsip ini dijalankan di Indonesia? Sesuatu yang baru yang kita temui di Kantor Pelayanan Pajak (KPP) saat ini, terutama disebagian besar wilayah perkotaan adalah keberadaan Account Representative (AR). AR adalah jabatan baru yang diperkenalkan dalam Struktur Organisasi Modern DJP RI. AR berada pada seksi Pengawasan dan Konsultasi (Waskon). Pada setiap KPP ada sekitar empat seksi Waskon inidengan jumlah AR untuk tiap seksi berkisar delapan orang. Masing-masing AR memegang beberapa Wajib Pajak tergantung jumlah Wajib Pajak di KPP tersebut. Disamping menjalankan fungsi pelayanan kepada Wajib Pajak, AR juga menjalankan fungsi pengawasan dan penerimaan pajak terhadap Wajib Pajak.

Fungsi pelayanan, yang dijalankan AR diantaranya: (1) Sebagai Liaison Officer KPP dengan WP; (2) Menjamin akurasi. konsistensi, kepastian, ketepatan dan efisiensi waktu dalam memberikan pelayanan kepada Wajib Pajak; (3) Membangun hubungan yang lebih terbuka didasari saling percaya antara WP dan KPP sehingga menciptakan peningkatan kepatuhan WP dalam memenuhi kewajiban dan haknya di bidang perpajakan dalam rangka menghindari pengenaan sanksi bagi WP; (4) Melakukan pemuktahiran data WP; (5) Menginformasikan perubahan ketentuan perpajakan.

AR bertindak sebagai sumber informasi dan melakukan koordinasi serta tindak lanjut dengan seksi terkait pada KPP sehubungan dengan: kepatuhan formal dan material WP, data matching, penerbitan produk hukum, pelayanan permohonan dan konsultasi Tugas AR yang cukup menonjol salah satunya adalah bertugas memberikan konsultasi kepada Wajib Pajak atas masalah-masalah perpajakan yang dialaminya. Konsultasi ini biasanya dilakukan per telepon ataupun via email. Sering juga Wajib Pajak datang langsung untuk sekedar berdiskusi tentang masalah-masalah pajak kepada ARnya.Tugas AR lainnya adalah memberikan bimbingan dan konsultasi tentang penerapan softwaree-SPT kepada Wajib Pajak.

\section{Prinsip Bantuan Khusus}

Prinsip keadilan memperkuat larangan yang lebih luas pada sebagian besar yurisdiksi terhadap diskriminasi secara umum. Ada peningkatan tanggung jawab untuk berhati-hati dalam hal mengambil tindakan dari badan-badan pemerintah dalam rangka mendukung sikap non diskriminasi. Undang-undang pajak biasanya memuat sejumlah peraturan yang menyatakan bahwa para Wajib Pajak memiliki hak untuk mendapatkan informasi, mendapatkan bantuan, dan hak untuk didengar.

Bagaimanapun hak untuk mendapatkan bantuan harus dijadikan sebagai suatu prinsip dasar dalam hubungannya dengan Wajib Pajak yang bersangkutan meminta bantuan khusus atau tertentu. Manfaat yang diperoleh akan samabesarnya, baik bagi kantor pajak maupun bagi para Wajib Pajak.Pada kenyataannya, seberapa besar dan banyaknya bantuan yang diberikan secara langsung akan dipengaruhi oleh kemampuan masing-masing negara atau yurisdiksi untuk mendanainya. Namun demikian, hal initidak dapat dijadikan alasan sehingga prinsip tersebut hanya dijadikan sebagai sebuah hak baru sebatas anjuran untuk dilaksanakan. Semua yurisdiksi harus melakukan apapun yang mereka bisa untuk memenuhi kebutuhan para Wajib Pajak yang memerlukan bantuan khusus. Tingkat bantuan akan berbeda-beda bergantung pada dana yang ada dan sumber paksaan. Oleh karena itu, adalah penting bagi semua Wajib Pajak agarprinsip bantuan ini dijadikan sebagai dasar bagi setiap administrasi pajak.

Undang-undang KUP di Indonesia tidak mengatur secara khusus tentang kewajiban DJP 
memberikan pelayanan bantuan khusus kepada Waijb Pajak. Namun sesuai Pasal 16 (4), 25 (6), 27 (4a), dan 36 (le), apabila diminta oleh Wajib Pajak, Direktur Jenderal Pajak wajib memberikan keterangan secara tertulis mengenai hal-hal tententu yang ingin diketahui oleh Wajib Pajak tentang dasar keputusan yang diterbitkannya. Demikian juga itikad baik lainnya ditunjukkan dengan fungsi pelayanan $A R$ yang mendukung hal tersebut. Fungsi pelayanan AR yang takkalah pentingnya bagi Wajib Pajak adalah memberikan bantuan khususdalam menyelesaikan permasalahan-permasalan yang dihadapi Wajib Pajak yang dipegangnya. Kemudian juga menyelesaikan permohonan pemindahbukuan, penerbitan Surat Perintah Pengembalian/Restitusi (SPP), memberikan imbalan bunga kepada Wajib Pajak yang permohonan keberatan atau bandingnya diterima, menyelesaikan permohonan pengurangan angsuran PPh Pasal 25, melakukan pembetulan STP, menyelesaikan permohonan perubahan tahun buku dan lain-lain. Pada KPP Pratama, tugas AR meliputi juga menyelesaikan permohonan pengurangan Pajak Bumi dan Bangunan. Untuk masalah-masalah yangrumit yang belum jelas aturannya, jika AR tidak dapat menyelesaikan, Wajib Pajak dapat melayangkan surat resmi kepada Kepala KPP, dan biasanya dijawab secara resmi pula oleh Kepala KPP.

Tugas AR adalah bertanggung jawab membantu seluruh kebutuhan administrasi yang dibutuhkan WP dalam memenuhi seluruh kewajiban perpajakannya; Bertindak sebagai sumber informasi dan melakukan koordinasi serta tindak lanjut dengan seksi terkait pada KPP sehubungan dengan: kepatuhan formal dan material WP, data matching, penerbitan produk hukum, pelayanan permohonan dan konsultasi.Tugas konsultasi yang diembannya tersebut tentu saja mensyaratkan AR memiliki pemahaman yang baik terhadap peraturan-peraturan pajak. Hanya saja seperti yang diakui sebagian pegawai DJP, sangat minim sekali kegiatan pendidikan dan pelatihan untuk meningkatkan kemampuan pegawai pajak yang dilaksanakan. Hal ini tentu berdampak rendahnya kapabilitas pegawai pajak terutama AR dalam memenuhi permintaan konsultasi dari Wajib Pajak.

\section{Prinsip Bertindak Secara Etis dan Profesional}

Siapa Wajib Pajak yang tidak mengharapkan untuk mendapatka nperlakuan yang etis dan profesional dari otoritas pajak? Sesuatu yang dapat diperdebatkan, bahwa dengan semakin luasnya kebutuhan untuk implementasi prinsip-prinsip tata kelola yang baik (Good Governance) dan praktek yang baik (Good Practice) dalam sistem perpajakan, serta untuk menjamin agar otoritas pajak tetap independen, adil, dan tidak memihak, maka tidak ada alasan untuk menjadikan etika dan profesionalisme sebagai suatu prinsip tersendiri atau khusus. Terdapat3 (tiga) alasan untuk mendukung hal tersebut (McLennan, 2003; Bentley, Turley, 2006; 2007;), yaitu: Pertama, luasnya akibat korupsi dalam pemerintahan dan otoritas pajak di seluruh dunia menunjukkan bahwa penting bagi para Wajib Pajak untuk memiliki aturan umum yang dapat mereka jadikan sebagai dasar dalam mengajukan keluhan melalui mekanisme penyelesaian masalah di kantor pajak, dan lebih tinggi lagi, melalui lembaga ombudsman pajak. Sangat jarang terjadi otoritas pajak mengakui para petugasnya bertindak secara tidak etis dan tidak profesional. Lebih jauh lagi sepertinya pemerintah tidak ingin mengedepankan prinsip tata kelola yang baik dan menggabungkannya dengan peraturan dari International Monetary Fund (IMF) yaitu Undang undang Praktek yang Baik dan Transparansi Fiskal. Setidaknya menyediakan suatu aturan umum yang memberikan beberapa dasar bagi perlindungan hak-hak administrative Wajib Pajak; Kedua, meskipun ada hukum, baik pidana maupun administratif, yang menginginkan perilaku sesuai etika dan tidak memihak, biasanya keadilan (dapat) diatur dalam hal-hal yang khusus, karena ada ganjaran-ganjaran yang dihubungkan dengan perilaku tersebut; dan Ketiga, sifat prinsip administrative pajak membuatnya berguna untuk melindungi baik WP maupun reputasi otoritas pajak.

Prinsip perilaku yang etis dan professional diwujudkan dalam beberapa bentuk pada kebanyakan peraturan perundang-undangan pajak. Perilaku profesional meliputi juga konsep tambahan di mana petugas pajak tidak boleh mengeluarkan suatu kesimpulan yang kurang baik (negatif)hanya karena seorang Wajib Pajak memilih untuk menggunakan hak-hak hukum atau administratif yang tersedia. Penerapan prinsip-prinsip bertindak secara etis dan profesional di Indonesia saat ini sudah menunjukkan perbaikan yang patut diberikan apresiasi. Reformasi perpajakan di segala lini yang telah disusun oleh DJP akan sia-sia jika tanpa dukungan dari pihak eksternal maupun dari pihak internal. Sebagai bukti keseriusan pemerintah dalam melangsungkan modernisasi pajak adalah dengan menyeimbangkan reward dan punishment serta menegakkan ketertiban etika, moral, dan integritas petugas pajak. 
Undang-undang No 16 tahun 2009 tentang KUP mewajibkan Menteri Keuangan untuk membuat kode etik pegawai Direktorat Jenderal Pajakyang harus dipatuhi (Pasal 36B). Pengawasan pelaksanaan dari kode etik tersebut dilakukan oleh Komite Kode Etik yang nantinya akan diatur berdasarkan Peraturan Menteri Keuangan. DJP pun telah menyusun sebuah Kode Etik Pegawai DJP yang diatur dalam Peraturan Menteri Keuangan Nol/PMK.3/2007 tanggal 23 Juli 2007 tentang 9 kewajiban pegawai dan 8larangan pegawai baik kepada masyarakat, Wajib Pajak, sesama pegawai, atau pihak lain dengan sanksi setinggi-tingginya pemberhentian dengan tidak hormat dan serendah-rendahnya pernyataan tidak puas secaratertulis. Kemudian juga diterbitkan SE33/PJ/2007 tentang Panduan pelaksanaan Kode Etik Pegawai DJP. Tercatat selama tahun 2006 terdapat210 pegawai pajak yang telah dijatuhkan sanksi disiplin dan selama Januari 2007 sebanyak 31 orang. Sanksi yang diterapkan terhadap pegawai pajak berdasarkan pasal 36B tersebut, tergantung kepada jenis pelanggaran yang dilakukan, yaitu: (1) yang karena kelalaiannya atau dengan sengaja menghitung atau menetapkan pajak tidak sesuai dengan ketentuan dikenai sanksi sesuai dengan ketentuan perundang-undangan; (2) yang dengan sengaja bertindak di luar kewenangannya yang diatur didalam ketentuan peraturan perundang-undangan perpajakan, dapat diadukan kepada unit internal Departemen Keuangan; (3) yang terbukti melakukan pemerasan dan pengancaman untuk menguntungkan diri sendiri secara melawan hukum akan dikenai sanksi berdasarkan Undang-Undang Hukum Pidana; (4) pegawai pajak yang menyalahgunakan kekuasaannya dengan memaksa Wajib Pajak untuk memberikan sesuatu, untuk membayar atau menerima pembayaran, kepada dirinya diancam dengan pidana sebagaimana dimaksud oleh Undang-undang No. 31/1999.

Namun, pegawai pajak tidak dapat dituntut baik secara perdata maupun pidana apabila dalam melaksanakan tugasnya didasarkan pada iktikad baik dan harus sesuai dengan ketentuan peraturan perundang-undangan perpajakan. Bagi DJP, dengan diberlakukannya kode etik yang mengikat dalam pelaksanaan tugas, di bawah pengawasan berbagai institusi pengawas, mulai dari komisi ombudsman, komite pengawas kode etik, dan InspektoratJenderal, akan mendorong penerapan prinsip profesionalisme dan etika dalam tubuh otoritas pajak Indonesia tersebut. Pasal 36C Undang-undang KUP menghen- daki Menteri Keuangan untuk membentuk komite pengawas perpajakan, yang ketentuannya diatur dengan Peraturan Menteri Keuangan. Untuk itu Menteri Keuangan telah mengeluarkan PMK No.54/PMK .09/2008.

Sebagai insentif atau reward terhadap pencapaian kinerja yang baikdari aparatur pajak, sesuai prinsip tata kelola yang baik, maka dalam Pasal 36D juga mengatur insentif sebagai berikut: (1) Direktorat Jenderal Pajak dapat diberi insentif atas dasar pencapaian kinerja tertentu; (2) Pemberian insentif tersebut ditetapkan melalui APBN; (3) Tata cara pemberian dan pemanfaatan insentif tersebut diatur dengan Peraturan Menteri Keuangan.Dengan diterapkannya kelima prinsip-prinsip administrasi yang telah dijelaskan di atas, maka Wajib Pajak akan memperoleh kenyamanan, keamanan dan kepastian hukum dalam memenuhi kewajiban administrative perpajakannya. Hanya dengan pelaksanaan administrasi pajak yang baik dengan tata kelola dan praktek yang benar, penuh etika dan profesionallah yang dapat memberikan perasaan aman dan nyaman serta penuh kepastian. Inilah hak-hak administratif Waijb Pajak yang secara implisit ada dalam prinsipprinsip administrasi tersebut.

Regulasi yang melingkupi administrasi pajak umumnya manjadi penentu bagaimana struktur dari sistem perpajakan dan membentuk otontas pajak. Regulasi yang membentuk/menciptakan otoritas pajak normalnya akan membekali mereka (otoritas pajak) dengan suatu kewenangan-kewenangan umum dalam tata administrasi suatu system perpajakan (Widodo dan Djesferis, 2008). Pemahaman tentang ruang lingkup dan batasan kekuasaan atau kewenangan biasanya akan dipengaruhi oleh bagaimana Wajib Pajak mengikuti aturan perpajakan.

Kerangka hukum dari administrasi pajak akan bergantung pada luasnya ruang lingkup kerangka hukum dan struktur administrasi dalam yurisdiksi negara tersebut. Berdasarkan analisis secara komparatif membuktikan bahwa terdapat kesamaan dalam kerangka hukum yang diterapkan di masingmasing negara, namun kita tidak dapat menyimpulkan begitu saja. karena nuansa lokal atau karakteristik khusus dari masing-masing Negara sangatlah bervariasi (fluralistik).

\section{KOMITE PENGAWAS PERPAJAKAN (TAX OMBUDSMAN}

Sesuai dengan namanya, lembaga semacam komite pengawas (ombudsman) didirikan dalam 
rangka untuk melakukan pengawasan terhadap (1) individu yang menjalankan kegiatan publik dan (2) pengawasan terhadap prosedur administrasi dan kebijakan publik yang menyimpang dari asas good governance. Ombudsman merupakan pihak yang independen yang menerima dan melakukan penyelidikan terhadap keluhan dari masyarakat terkait dengan tindakan administrasi.Selain itu, ombudsman juga mempunyai otoritas untuk menyampaikan masukan melalui suatu publikasi tertentu (Bala dan Biswas, 2005: 27-40). Di India, pembentukan tax ombudsman juga dimaksudkan untuk mendengar keluhan wajib pajak yang diperlakukan secara sewenang-wenang dan untuk memfasilitasi penyelesaiannya (Bender, 2003:314).

Ombudsman pertama kali didirikan di Swedia melalui Swedish Constitution Act 1809. Terkait dengan fungsi lembaga komite pengawasan, ada dua macam pengawasan di sini, yaitu (a) pengawasan terhadap individu yang melaksanakan kebijakan publik, dan (b) pengawasan terhadap sistem administrasi dan kebijakan publik.

Seperti telah disebutkan di atas, di Amerika Serikat, komite pengawas perpajakan dikenal dengan nama National Taxpayer Advocate yang merupakan lembaga independen yang berada dalam satu atap dengan IRS. Adapun fungsi yang dijalankan oleh National Taxpayer Advocate adalah sebagai berikut (National Taxpayer Advocate, 2009:1):(1) Membantu wajib pajak dalam memutuskan permasalahan wajib pajak dengan IRS; (2) Mengidentifikasi permasalahan yang sering terjadi antara wajib pajak dan IRS; (3) Mengusulkan untuk melakukan perubahan dalam administrasi perpajakan untuk menghilangkan permasalahan yang sering terjadi antara wajib pajak dan IRS; dan (4) Memberikan rekomendasi perubahan atas ketentuan peraturan perundang-undangan perpajakan terkait dengan permasalahan yang sering terjadi antara wajib pajak dan IRS dalam rangka untuk menghilangkan permasalahan tersebut.

Tujuan dibentuknya Komite Pengawas Perpajakan berdasarkan Peraturan Menteri Keuangan Nomor 54/PMK.09/2008 tanggal 17 April 2008 adalah sebagai berikut: (1) Meminta keterangan kepada pihak terkait tentang prosedur, sistem, dan kebijakan di bidang perpajakan; (2) Mengkaji masukan dari pihak lain mengenai prosedur, sistem, dan kebijakan di bidang perpajakan; (3) Menghimpun masukan dari masyarakat atau pihak lain dan mengkaji ketentuan dan pelaksanaan peraturan perundang-undangan perpajakan; dan (4) Memberi rekomendasi atau saran untuk perbaikan dan penyempurnaan terhadap prosedur, sistem, ketentuan peraturan perundang-undangan, dan kebijakan di bidang perpajakan.

Kalau kita bandingkan fungsi dan kewenangan antara Komite Pengawas Perpajakan yang dibentuk di Indonesia dan National Taxpayer Advocate di Amerika Serikat pada dasarnya adalah mempunyai kesamaan yaitu sama-sama (a) mengkaji permasalahan yang terkait dengan prosedur administrasi dan kebijakan perpajakan dan (b) memberikan rekomendasi atas prosedur, sistem administrasi dan kebijakan perpajakan. Dengan kata lain, fokusnya pada pengawasan sistem prosedur administrasi dan kebijakan perpajakan dan bukannya pengawasan terhadap individu yang menjalankan kebijakan perpajakan. Disamping itu, anggota komite juga harus proaktif mencari masukan serta mengkaji permasalahan dan tidak hanya mengandalkan masukan dari masyarakat saja.

Terkait dengan fungsi mana yang lebih ditekankan, ombudsman pajak di Italia, selain membantu wajib pajak yang sedang menghadapi permasalahan dengan otoritas pajak, juga melakukan identifikasi permasalahan sistem administrasi pajak yang sedang berjalan (Romano, 2001: 28).Dengan demikian, anggota komite pengawasan perpajakan atau tax ombudsman dituntut kemampuannya secara proaktif untuk memberikan masukan kepada otoritas pajak apabila terdapat kelemahan dalam sistem administrasi pajak (Bentley, 1998: 56).

Sebagai lembaga pengawas, idealnya kedudukan dari komite pengawas perpajakan atau tax ombudsman harus independen terhadap lembaga yang di awasi. Menurut Leon Yudkin, komite pengawas perpajakan tidak boleh ditempatkan di lembaga eksekutif karena akan menimbulkan konflik kepentingan (Yudkin, 1971). Akan tetapi, dalam praktik di beberapa negara, kedudukan komite pengawas perpajakan ini bervariasi. Di Bangladesh, tax ombudsman merupakan lembaga yang anggotanya diangkat oleh presiden. Sedangkan di Amerika Serikat, komite pengawas perpajakan yang dikenal dengan namaNational Tax Advocate berada di dalam Internal Service Revenue (IRS).

5. Peran Strategis Komite Pengawas Perpajakan
Di Indonesia Dengan melihat berbagai pandangan yang telah diuraikan di muka, maka peran strategis yang dapat dilakukan oleh Komite Pengawas Perpajakan di 
Indonesia untuk meningkatkan kepatuhan wajib pajak yaitu dengan cara melakukan berbagai saran pembenahan yang pada dasarnya terdiri dari empat hal utama sebagai berikut: (a) legislasi pembuatan kebijakan dan hukum perpajakan, (b) prosedur administrasi perpajakan, (c) ketentuan tentang penyelesaian sengketa pajak, (d) ketentuan tentang kuasa wajib pajak, dan permasalahan lainnya.

Berikut ini gambaryang menguraikan keempat hal pokok tersebut yang harus menjadi kajian utama dari Komite Pengawas Perpajakan:

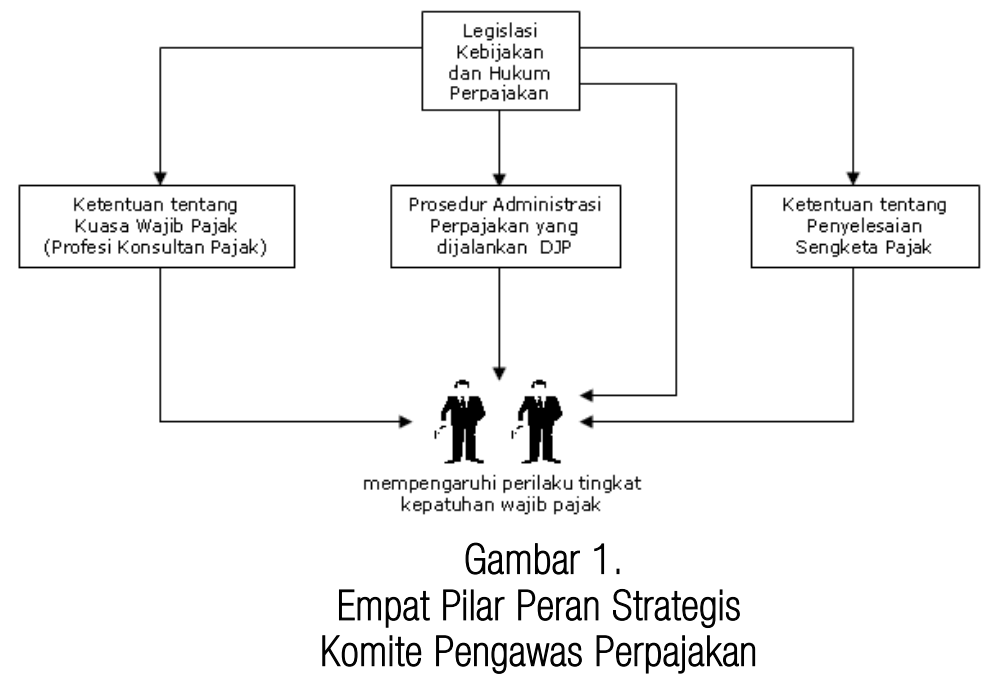

Legislasi Kebijakan dan Hukum Perpajakan

Pasal 23a UUD 1945 menyatakan bahwa pajak dan pungutan lain yang bersifat memaksa untuk keperluan negara diatur dalam undang-undang. Pengaturan seperti yang dinyatakan dalam UUD 1945 tersebut mengandung arti bahwa tidak ada pajak yang dapat dipungut tanpa adanya persetujuan dari rakyat (melalui wakil rakyat yang ada di DPR).Dalam undangundang perpajakan yang kita anut, sering terjadi kebijakan dan ketentuan perpajakan tertentu didelegasikan dan diatur lebih lanjut di dalam ketentuan peraturan perundang-undangan yang kedudukannya dibawah undang-undang.

Di Meksiko, dalam rangka untuk memberikan kepastian hukum, penentuan unsurunsur (penghasilan dan biaya) untuk menghitung penghasilan kena pajak (tax base) dan tarif pajak (tax rate) harus diatur secara jelas dalam undang-undang perpajakan (Moliho,2004, hal. 551).Dengan kata lain melalui proses persetujuan antara wakil rakyat (yang juga wakilnya wajib pajak) dengan negara yang diwakili oleh pemerintah. Jadi, pengaturan tentang tax base dan tax rate tidak boleh didelegasikan kepada peraturan perundang-undangan yang kedudukannya ada di bawah undang-undang yang dalam prosesnya tidak melalui persetujuan dari rakyat.
Terkait dengan pendelegasian dan pengaturan lebih lanjut ketentuan perpajakan kepada peraturan perundang-undangan yang tingkatannya di bawah undang-undang, disini dituntut peran Komite Pengawas Perpajakan yang mewakili wajib pajak untuk dapat menjadi "mediator" dalam rangka melakukan dengar pendapat kepada pemerintah terhadap rencana pembuatan kebijakan perpajakan yang nantinya akan diterapkan kepada wajib pajak. Kalau hal ini dilakukan, diharapkan kebijakan pajak yang akan diperlakukan tersebut dapat diterima dan tidak mendapat penolakan dari wajib pajak. Dengan demikian, tujuan pemerintah untuk mengumpulkan pajak dari wajib pajak dapat terlaksana dengan efektif serta akan mengurangi tindakan constitutional review ke Mahkamah Konstitusi dan judial review ke Mahkamah Agung yang dilakukan oleh wajib pajak.

\section{Prosedur Administrasi Pajak}

Komite Pengawas Perpajakan dapat memberikan masukan atas model pelayanan yang seharusnya dilakukan oleh kantor-kantor pelayanan pajak seperti dapat dilihat dalam Tabel 1 sebagai berikut ini: 
Tabel 1.

Model Pelayanan Administrasi

\begin{tabular}{lcl|}
\hline \multicolumn{1}{c}{ Dari } & diubah & \multicolumn{1}{c|}{ Menjadi } \\
\hline Sebutan "Wajib Pajak" (WP) & $\rightarrow$ & $\begin{array}{l}\text { "Klien" sebagai bentuk penghargaan kepada pembayar pajak, karena } \\
\text { telah membiayai Negara melalui pajak }\end{array}$ \\
\hline Pelayanan berdasarkan segmentasi (fungsional) & $\rightarrow$ & Pelayanan terpadu "one-stop shop" \\
\hline Komunikasi Melalui Surat & $\rightarrow$ & Komunikasi melalui elektronik "bank account \\
\hline Komunikasi secara pasif & $\rightarrow$ & Komunikasi secara proaktif \\
\hline $\begin{array}{l}\text { Model pelayanan yang sifatnya "memberikan } \\
\text { Bantuan" }\end{array}$ & $\rightarrow$ & Model pelayanan yang sifatnya "membidik" \\
\hline
\end{tabular}

Sumber: Hamilton (2003:575)

\section{Penyelesaian Sengketa Pajak}

Sama seperti di banyak negara, proses penyelesaian atas sengketa pajak (ketetapan pajak) diselesaikan melalui dua tahapan, yaitu: (1) penyelesaian di tingkat administrasi (dikenal dengan nama proses keberatan) dan (2) penyelesaian di tingkat badan peradilan apabila penyelesaian di tingkat administrasi tidak dicapai kesepakatan.
Di Indonesia, saat ini kecenderungan yang terjadi adalah penyelesaian sengketa pajak kebanyakan diselesaikan di tingkat pengadilan pajak. Hal ini dapat dilihat banyaknya kasus sengketa pajak yang menumpuk di Pengadilan Pajak yaitu sekitar 9.400 (kompas.com, 2010).Dari kasus-kasus tersebut, sebagian besar dimenangkan oleh wajib pajak seperti terlihat dalam Tabel 2.

Tabel 2.

Putusan Pengadilan Pajak

\begin{tabular}{|c|c|c|c|c|c|c|c|c|}
\hline \multirow[t]{2}{*}{ No. } & \multirow[t]{2}{*}{ Jenis Putusan } & \multicolumn{7}{|c|}{ Tahun } \\
\hline & & 2002 & 2003 & 2004 & 2005 & 2006 & 2007 & 2008 \\
\hline \multirow[t]{2}{*}{1} & Permohonan banding/ gugatan dikabulkan seluruhnya & 346 & 519 & 783 & 991 & 863 & 1.246 & 1.540 \\
\hline & $\%$ atas jumlah putusan & 26,86 & 32,74 & 35,35 & 33,30 & 35,81 & 39,00 & 40,82 \\
\hline \multirow[t]{2}{*}{2} & Permohonan banding/gugatan dikabulkan sebahagian & 210 & 218 & 428 & 495 & 586 & 600 & 736 \\
\hline & $\%$ atas jumlah putusan & 16,30 & 13,75 & 19,32 & 16,63 & 24,31 & 18,51 & 19,50 \\
\hline \multirow[t]{2}{*}{3} & Permohonan banding/ gugatan dibatalkan & 12 & 67 & 207 & 637 & 100 & 119 & 114 \\
\hline & $\%$ atas jumlah putusan & 0,93 & 4,23 & 9,34 & 21,40 & 4,15 & 3,67 & 3,02 \\
\hline \multirow[t]{2}{*}{4} & Permohonan banding/ gugatan ditolak & 162 & 220 & 240 & 304 & 318 & 406 & 751 \\
\hline & $\%$ atas jumlah putusan & 12,57 & 13,88 & 10,83 & 10,21 & 13,19 & 12,53 & 19,90 \\
\hline \multirow[t]{2}{*}{5} & $\begin{array}{l}\text { Permohonan banding/ gugatan tidak dapat diterima } \\
\text { (ditolak secara formal) }\end{array}$ & 543 & 554 & 549 & 545 & 536 & 843 & 627 \\
\hline & \% atas jumlah putusan & 42,16 & 34,95 & 24,78 & 18,31 & 22,24 & 26,01 & 16,62 \\
\hline
\end{tabular}

Sumber: Suhendro (www. setpp. depkeu.go.id 2010)

Dengan menumpuknya perkara di tingkat Pengadilan Pajak dan banyaknya perkara yang dimenangkan oleh wajib pajak, pertanyaan yang layak diajukan adalah bagaimana proses penyelesaian sengketa pajak di tingkat administrasi atau keberatan apabila dikaitkan dengan bentuk pelayanan kepada wajib pajak? Sebagai bagian dari pelayanan kepada wajib pajak seharusnya penyelesaian sengketa pajak di tingkat keberatan harus benar-benar mempertimbangkan aspek keadilan, sesuai dengan fakta, dan ketentuan perundang-undangan yang berlaku. Jangan sampai atas perkara yang sama yang di tingkat Pengadilan Pajak yang selalu dimenangkan oleh wajib pajak tidak dijadikan acuan oleh Direktorat Jenderal Pajak.
Di Jepang, apabila pengadilan banding memenangkan wajib pajak maka otoritas pajak akan menyesuaikan peraturan perundang-undangan perpajakannya untuk disesuaikan dengan putusan banding (Nakazato, 2004:83.). Hal ini dilakukan dalam rangka untuk kepastian hukum bagi wajib. Dengan demikian, terhadap kasus-kasus yang sama yang terjadi dikemudian hari tidak perlu lagi dibawa ke tingkat pengadilan. Tentunya ini akan mengurangi cost of compliance wajib pajak karena tidak perlu mengeluarkan biaya, waktu dan energi untuk membawa sengketa pajak ke tingkat pengadilan. Dengan pendekatan yang dilakukan di Jepang tersebut, jumlah kasus sengketa pajak yang dibawa di tingkat pengadilan sangat sedikit dan sebagian besar dimenangkan oleh pemerintah. Hal ini menunjukkan 
bahwa penyelesaian sengketa pajak di tingkat administrasi (eksekutif) cukup memuaskan wajib pajak.

Belanda juga melakukan hal yang sama dengan Jepang, yaitu apabila Mahkamah Agung Belanda memenangkan wajib pajak dan ketika otoritas pajak tidak setuju dengan putusan Mahkamah Agung maka akan mengajukan kasus yang sama kepada Mahkamah Agung. Akan tetapi, apabila Mahkamah Agung tetap memenangkan wajib pajak maka otoritas pajak akan merubah ketentuan perpajakannya (Raad, 2004:95).

Dalam rangka untuk memberikan kepastian hukum dan meringankan compliance costwajib pajak, Komite Pengawas perpajakan dapat melakukan tugas untuk mengidentifikasi kasus-kasus sengketa pajak yang dibawa ke pengadilan dan menganalisis ketentuan perpajakan mana yang perlu dirubah atau tidak. Tugas ini selaras dengan apa yang dikatakan oleh Duncan Bentley bahwa tax ombudsman mempunyai tugas yang luas dalam rangka meringankan beban administrasi wajib pajak (Bentley, 2007:170).

\section{Ketentuan tentang Kuasa Wajib Pajak}

Terkait dengan kebijakan tentang kuasa wajib pajak dan profesi pajak, dalam ketentuan yang berlaku saat ini di Indonesia menimbulkan cost of compliance yang tinggi karena terdapat upaya untuk mengarahkan wajib pajak untuk menggunakan jasa konsultan pajak atau mewajbkan pegawai pajak dari wajib pajak untuk mengikuti sertifikasi yang diselenggarakan oleh suatu profesi konsultan pajak tertentu. Hal ini tentu akan menciptakan biaya adminstrasi perpajakan yang tinggi bagi wajib pajak. Tentu ini sangat bertentangan dengan tujuan perubahan UU Nomor 16 tahun 2009 tentang Perubahan Ketiga UU Nomor 6 tahun 1983 tentang Ketentuan Umum dan Tata Cara Perpajakan yaitu untuk meningkatkan efisiensi pemungutan pajak dalam rangka mendukung penerimaan negara. Hal ini selaras dengan Duncan Bentley yang menyatakan bahwa meminimalkan cost of compliance wajib pajak akan berdampak kepada peningkatan penerimaan pajak.

\section{Permasalahan Lainnya}

Belajar dari laporan komite pengawas perpajakan di Amerika Serikat (National Taxpayer Advocate), permasalahan seperti disajkan dalam Tabel 3 di bawah ini perlu menjadi perhatian Komite Pengawas Perpajakan di Indonesia karena sering dikeluhkan oleh wajib pajak Amerika Serikat.

Tabel 3

Permasalahan yang Sering Dikeluhkan oleh Wajib Pajak di Amerika Serikat

\begin{tabular}{lccc}
\hline Permasalahan & 2006 & 2007 & 2008 \\
\hline Restitusi & 27.781 & 31.521 & 46.680 \\
\hline Pemeriksaan Pajak & 47.703 & 59.601 & 60.051 \\
\hline Penagihan Pajak & 43.552 & 43.706 & 42.418 \\
\hline Dokumentasi & 52.775 & 44.552 & 58.888 \\
\hline Sanksi & 12.328 & 15.716 & 13.705 \\
\hline Penyidikan Pajak & 21.385 & 12.121 & 11.103 \\
\hline Prosedur Administrasi/Ketentuan Perundangan & 12.585 & 12.121 & 11.103 \\
\hline Banding & 2.618 & 2.498 & 2.841 \\
\hline Bunga & 1.029 & 1.249 & 1.235 \\
\hline
\end{tabular}

Sumber: National Taxpayer Advocate, Report to Congress, Fiscal Year 2010 Objectives, 30 Juni 2009.

\section{KESIMPULAN}

Berdasarkan uraian yang telah dijelaskan sebelumnya, maka kesimpulan dari tulisan ini adalah(1) Pemberian pelayanan yang sebaik mungkin kepada wajib pajak akan menaikkan tingkat kepatuhan wajib pajak; (2) Tingginya tingkat kepatuhan wajib pajak dengan sendirinya akan meningkatkan penerimaan pajak; (3) Peran Komite Pengawas Perpajakan adalah untuk memastikan bahwa wajib pajak telah dilayani sebaik mungkin oleh Direktorat Jenderal Pajak. Pertama memastikan wajib pajak telah diberi pelayanan (dalam hal kebijakan, hukum, dan administrasi; Kedua Dirjen Pajak memberikan pelayanan optimal; Ketiga Komite Pengawas Perpajakan dan Dirjen Pajak secara sinergi memberikan Pelayanan yang yang optimal dan pada gilirannya peningkatan penerimaan pajak akan tercapai. Dengan kata lain terbentuknya sinergi antara Direktorat Jenderal Pajak dan Komite Pengawas Perpajakan dapat meningkatkan penerimaan pajak sebagaimana disajikan dalam Gambar 2 berikut ini: 


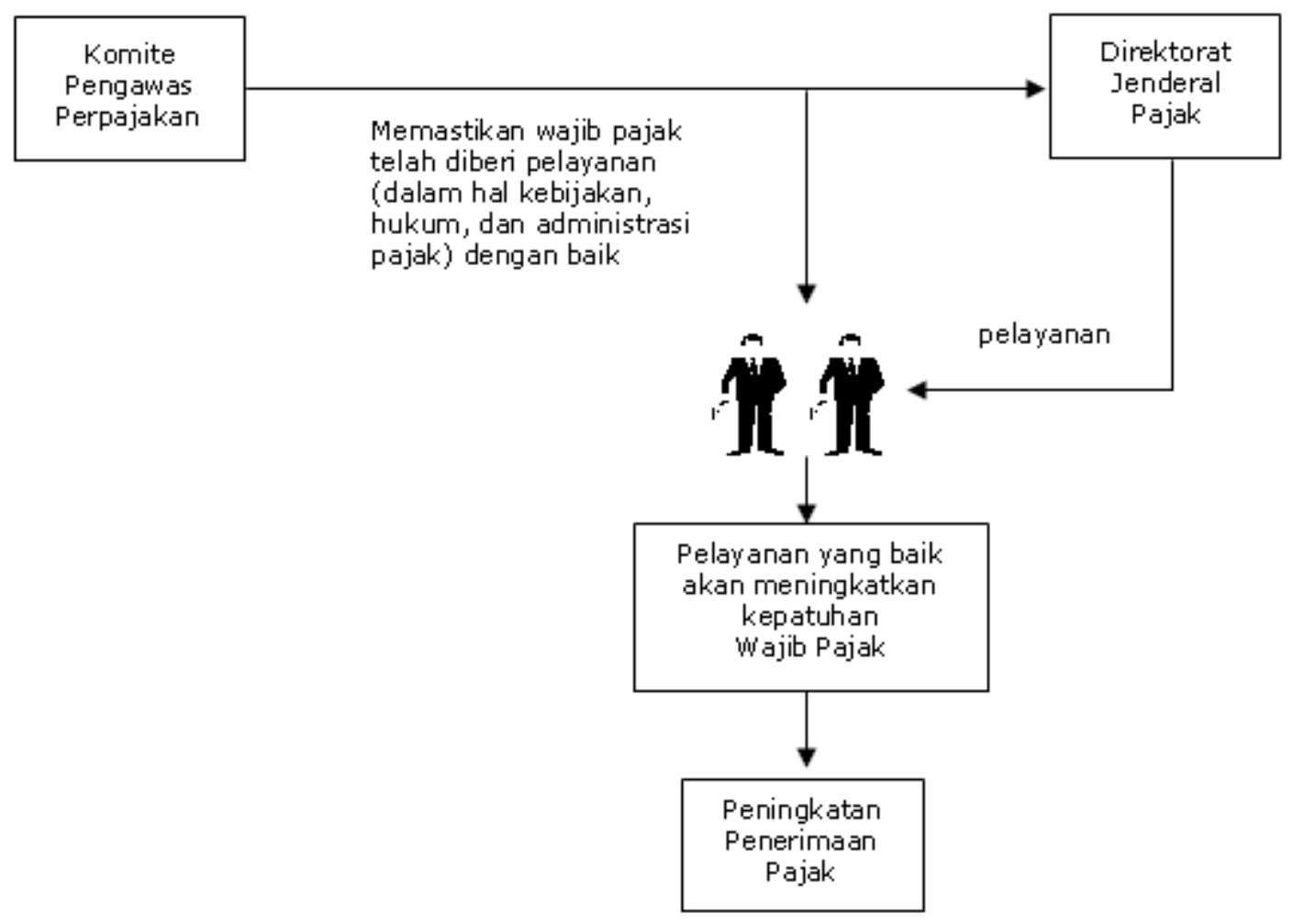

Gambar 2.

Peran Sinergisitas antara Komite Pengawas Perpajakan dan Direktorat Jenderal Pajak dalam meningkatkan Penerimaan pajak

\section{DAFTAR PUSTAKA}

Alink, Matthijs and Victor Van Kommer, 2009. The Dutch Approach: Description of the Dutch Tax Administration, Second Revised Edition, IBFD.

Bala, Swapan Kumar Bala dan Pallb Kumar Biswas. 2005. Tax Ombudsman in Bangladesh: An Analytical Review of the Regulatory Framework. The Cost and Management, Vol. 33 No. 6 November-December, pp. 27-40.

Bender, Lisa J., 2003. "India: Sing Announces Measures to Improve Tax Dispute Resolution", dalam Tax Notes International.

Bentley, Duncan 1998. Taxpayers' Right: An International Perspective, The Revenue Law. , 2007. Taxpayers' Rights: Theory, Origin and Implementation, Kluwer Law International.

Hamilton, Stuart 2003. "Putting the Client First: The Emerging Coperation Copernican Revolution of Tax Administration", dalam Tax Notes International.

Kompas.com, 14 Oktober 2009.
Moliho, Oscar., 2004. "Limit on the Taxing Power of the Mexican Government". BIFD.

Nakazato, Minoru Mark Ramseyer, dan Yasutaka, 2004. "General Description Japan," dalam Comparative Income Taxation, Kluwer Law International.

National Taxpayer Advocate, 2009. Report to Congress: Fiscal Year 2010 Objectives, 30 Juni.

OECD, 1999. Centre for Tax Policy and Administration, Principles of Good Tax Administration-Practice Note (GAP001), 1999 amended 2001.

Pemerintah $\mathrm{Rl}, \quad 2007$. PMK Nomor 54/PMK.09/2008 tanggal 17 April 2008 ini merupakan amanah dari Pasal 36C UU Nomor 6 tahun 1983 tentang Ketentuan Umum dan Tata cara Perpajkan sebagaimana telah beberapa kali diubah terakhir dengan UU Nomor 28 tahun 2007.

Raad, Kees van 2004. General Description The Netherlands. Comparative Income Taxation, Kluwer Law International. 
Romano, Carlo "Private Rulling System in the EU Member States: A Comparative Survey", dalam European Taxation.

Scales, Sirena J. 2005. "Bangladesh: Parliament Approves Creation of Tax Ombudsman Post", dalam Tax Notes International.
Suhendro,Winarto. 2009. "Pengadilan Pajak Sebagai Pengadilan Khusus di Lingkungan Peradilan Tata Usaha Negara", www.setpp.depkeu.go.id.

Yudkin, Leon., 1971. A Legal Structure of Effective Income Tax Administration, Cambridge: Harvard Law School, 